\title{
Genotyping of Mycobacterium leprae in a Son-and-Father Pair of Patients Indicated the Possible Mode of Leprosy Transmission: a Case Report
}

\author{
Hendra GUNAWAN¹, Irma FAKHROSA, Nia AYU SARASWATI, Muljaningsih SASMOJO, \\ Reti HINDRITIANI, Oki SUWARSA
}

${ }^{1}$ Department of Dermatology and Venereology, Faculty of Medicine, Universitas Padjadjaran - Dr. Hasan Sadikin Hospital, Bandung, Indonesia

*Correspondence: Hendra Gunawan, E-mail: endaguna@yahoo.com

UDC 616.5-002.73

\begin{abstract}
One of the success indicators of the World Health Organization (WHO) leprosy eradication program is the decreasing number of new cases of pediatric leprosy with a grade 2 disability. A case of borderline lepromatous (BL) leprosy with partial claw hand in a 13-year-old boy was reported. On physical examination, we found claw fingers on the fourth and fifth fingers of the left hand accompanied by hypoesthetic erythematous plaques on both cheeks. The patient also presented with the enlargement of bilateral great auricular, ulnar, and peroneal nerves. The bacteriological examination showed the bacterial index $3+$ and morphological index $35 \%$. The results of histopathological and serological anti-phenolic glycolipid-I examinations supported the diagnosis of BL type of leprosy. Genotyping of Mycobacterium leprae by variable number tandem repeat of the patient showed 24 copies thyminethymine-cytosine that were similar to his father, who had been diagnosed with leprosy 12 years before, without adequate therapy. The result indicated the possibility of leprosy transmission from the father to a son. This case report revealed the presence of leprosy in children with a multibacillary infection who have been living with leprosy family members. Genotyping seems to be feasible for epidemiological analysis of leprosy transmission.
\end{abstract}

Key words: Leprosy + transmission; Mycobacterium leprae; Leprosy, Borderline; Genotyping Techniques; Case Reports

\section{Introduction}

Leprosy is one of the health problems in developing countries (1) including Indonesia (2). The incidence rate of leprosy in children can be an indicator of the prevalence of leprosy in the general population (3), and related to the presence of an active source of transmission (4). Leprosy in children is still common, especially in greater endemic countries (5). The risk of leprosy transmission is increased from five to ten times if one family member has leprosy, particularly if it is lepromatous leprosy (LL) type (6). The proportion of leprosy incidence in children varies in every country, ranging from $0.6 \%$ in Argentina (6), $10.3 \%$ in Sri Lanka (7), $11 \%$ in the Philippines (5), to $32 \%$ in Africa (6). Based on the data from the Ministry of Health of Indonesia in 2014 , out of 16,131 new cases of leprosy in
Indonesia, 1,755 cases (10.88\%) were diagnosed in children aged 0-14 years and 1,525 cases $(9.45 \%)$ were with disability grade $2(8)$.

Genotyping of Mycobacterium leprae (M. leprae) can be used to recognize whether the patients have been infected with the same strain, therefore being suggestive of belonging to the same transmission mode (9). This case report was aimed at providing an example of leprosy case in children with a grade 2 disability whose father was suspected as the source of transmission, through genotyping of $M$. leprae by variable number tandem repeat (VNTR).

\section{Case Report}

A 13 year-old-boy presented with weakness on the fourth and fifth fingers of the left hand, accompanied by skin lesions on the 

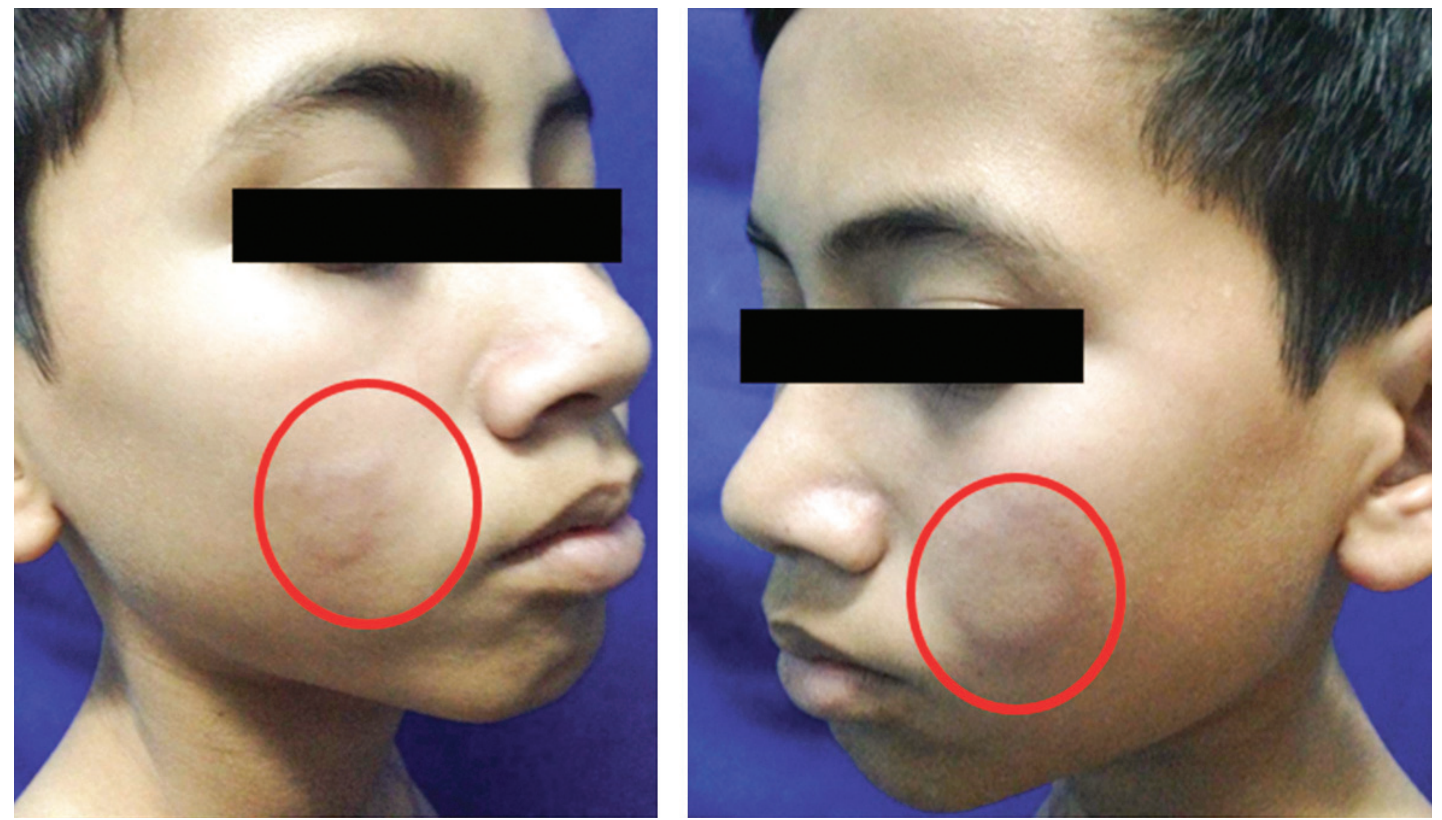

Figure 1. Hypoesthetic erythematous plaques

cheek. Four years prior to consultation, he often felt tingling in his left hand. Six months afterwards, the fourth and fifth fingers of the patient's left hand became weak. One year later, redness on both cheeks developed in nummular-size. He had never received any treatment before. Physical examination showed clawing on the fourth and fifth fingers of the left hand, accompanied by hypoesthetic erythematous plaques on the cheek and thickening of both ulnar, great auricular, and common peroneal nerves. Bacteriological examination revealed bacterial index $(\mathrm{BI}) 3+$ and morphological index (MI) $35 \%$. Histopathological examination of the erythema- tous plaque showed granuloma consisting of lymphocytes, epithelioid cells, and foamy macrophages. Serological examination revealed $1.017 \mathrm{u} / \mathrm{mL}$ anti-phenolic glycolipid-I (anti-PGL-I) immunoglobulin (Ig) M and 1.052 $\mathrm{u} / \mathrm{mL}$ anti-PGL-I IgG. Genotyping of $M$. leprae by VNTR of the patient showed 24 copies thymine-thymine-cytosine (TTC) that were similar to his father, who had been diagnosed to have leprosy 12 years before. Initially, the patient's father developed anesthetic hypopigmented macules on his chest, back, and both upper arms, associated with hypoesthetic soles. He also noted the thickening of both pinna, hence he consulted our hospital
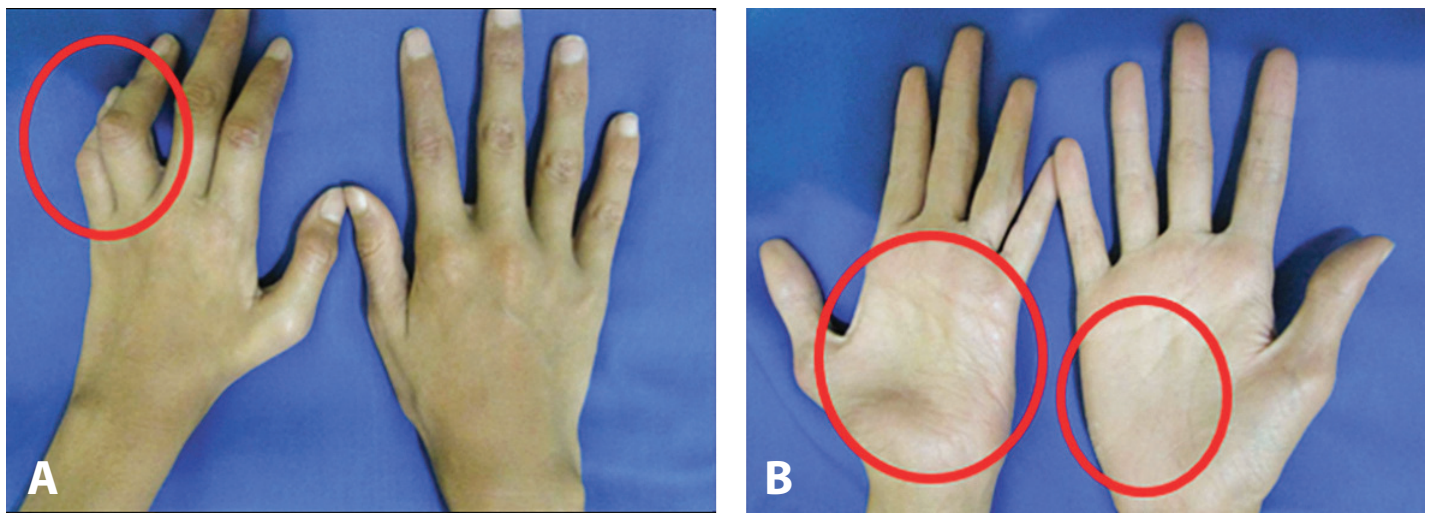

Figure 2. (A) Clawing of 4th and 5th fingers on the left hand Thenar and hypothenar atrophy on the left hand $(B)$ Hypothenar atrophy on the right hand 


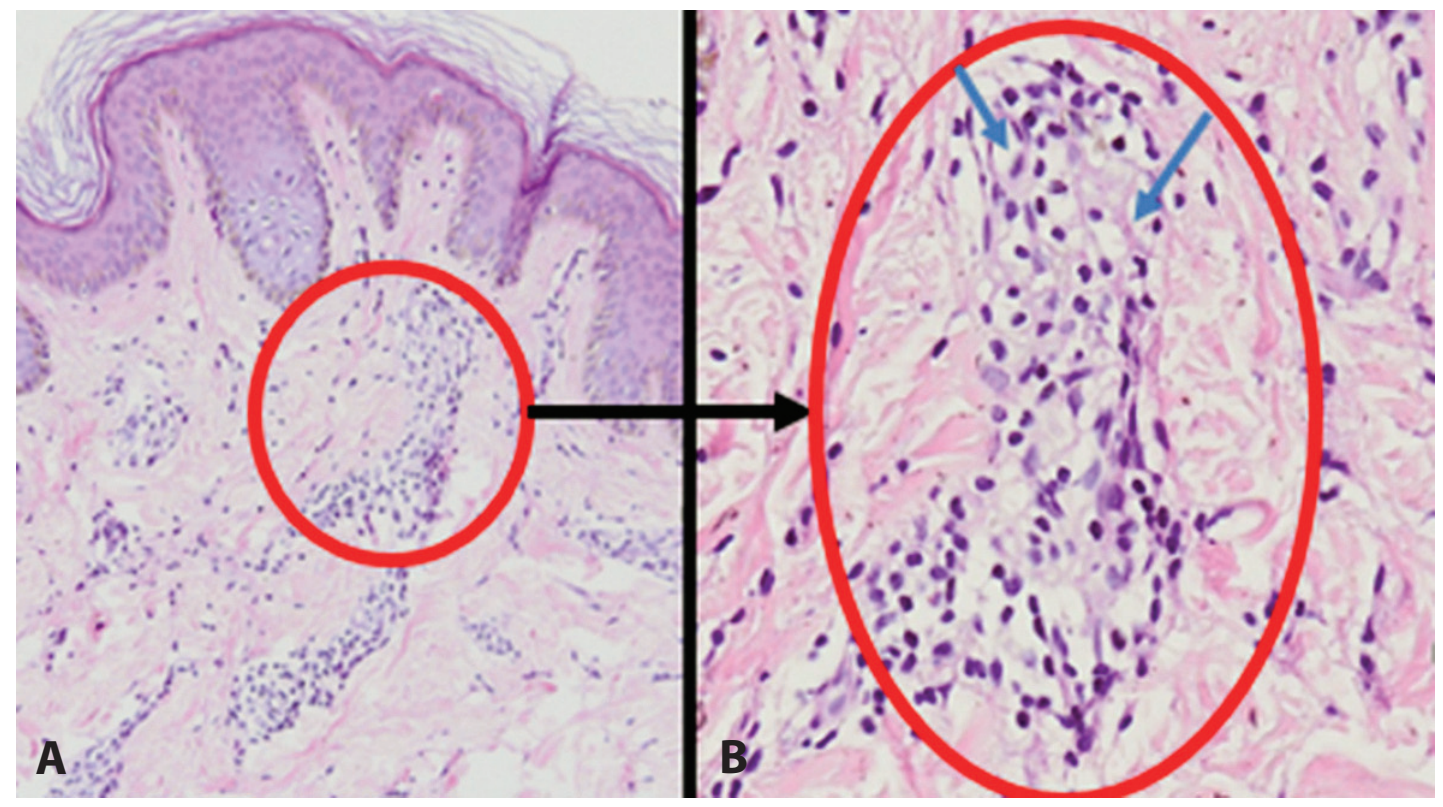

Figure 3. The pathologic features are (A) epidermal, dermal, massive infiltration of neutrophils and (B) foamy macrophages (hematoxylin-eosin(HE), original magnification 200x)

and was diagnosed to have leprosy. The patient's father received multidrug therapy (MDT) but he consumed the drug for only three months of therapy and did not collect the treatment regularly, then he became a defaulter leprosy patient. The recent serological examination of the patient's father was $101,000 \mathrm{u} / \mathrm{mL}$ for anti-PGL-I IgM and $448 \mathrm{u} /$ $\mathrm{mL}$ for anti-PGL-I IgG. Histopathological examination from clinically normal appearing skin on his right knee showed granuloma consisting of foam cells and some lymphocyte that supported the diagnosis of LL type.

The patient was diagnosed as borderline lepromatous (BL) leprosy with grade 2 disability, then received MDT for multibacillary (MB) WHO therapy and home physiotherapy program for range of movement of four extremities and fingers exercise to prevent further deformities.

\section{Discussion}

Leprosy is an infectious disease caused by $M$. leprae with a long incubation period (7), therefore this disease usually occurs in adults. However, children are also susceptible to leprosy (3). The leprosy rate in children is an important epidemiological indicator in determining the transmission rate of leprosy in one area $(3,4)$. The mean age of children with lep- rosy is generally between 10-14 years. Based on several studies, the incidence ratio of boy and girl with leprosy is $2: 1$ (3). One of the indicators of success of eradication program of leprosy according to the WHO is the decreasing number of new leprosy cases in children with disability (2). One study performed by Liangbin, et al.(10) in China (2011) showed that $80 \%$ of 165 leprosy patients in children aged between 7 and 11 years have family members suffering from leprosy and $13.3 \%$ of these patients develop grade 2 disability. Imbiriba et al. (11) included 474 leprosy patients aged 0-14 years in their study in Manaus, North Brazil.

Leprosy spreads through airborne transmission $(6,12)$ and direct skin contact $(2)$. The risk of leprosy transmission increases five to ten times if one family member has leprosy (6). Clinical features of leprosy in children are not as clear as in adults (3). Sensory function tests are also difficult to assess and bacteriological examination is generally negative. Histopathological examination may help the diagnosis of leprosy in children (3). Various studies have shown that leprosy in children occurs more often in tuberculoid type than in lepromatous type $(3,6)$.

In this case, leprosy with grade 2 disability was found in a 13-year-old boy, whose father had been diagnosed to have leprosy 12 
years before. In this patient, there were only two skin lesions of hypoesthetic erythematous plaques in both cheeks, accompanied by symmetrical nerves enlargement. Bacteriological, serological, and histopathological examinations supported the diagnosis of BL leprosy.

The genotyping examination of $M$. leprae was performed to identify strains and sources of transmission of $M$. leprae (13). In this patient, genotyping of $M$. leprae showed VNTR counts of 24 copies TTC. The source of the patient's leprosy is thought to have originated from his father who had been diagnosed to have leprosy 12 years before with no adequate therapy. This can be seen from the results of the genotyping of $M$. leprae in the patient's father which showed the VNTR number of 24 copies TTC that were similar to the patient.

Genome sequence from an isolate of $M$. leprae is now available for strain typing to identify the transmission chains using leprosy multiple-locus VNRT analysis (14). VNRT pattern was related to those found in some multicase families which were detected in patients in the same regions, indicating the utility of VNRT strain typing to identify and detect transmission (15). One study of $M$. leprae genotyping using VNRT analysis by Weng et al (15). in China showed that out of eleven families, six families had the similar $M$. leprae VNRT profiles. The other study performed by Masuoka et al. (13) in North Sulawesi revealed that out of five families whose members had leprosy, three families showed identical TTC genotypes, while the other two families had different TTC genotype between a father, his son, and among brothers. The inconsistency of the genotypes $M$. leprae isolated in the family members living in the same household indicates that leprosy patients are not always a source of infection for other family members (13). In this case, the result of $M$. leprae VNRT genotyping revealed a similar result from the patient and his father, therefore indicating that leprosy was transmitted to him from his father.

\section{Conclusion}

The new cases of leprosy in children with grade 2 disability are still detected and it is suspected that a family member may be the source of transmission. Genotyping of $M$. leprae seems to be feasible for epidemiological analysis of leprosy transmission.

\section{References}

1. Silva MR, Castro MR. Mycobacterial infections. In: Bolognia JL, Jorizzo JL, Rapini RP, editors. Dermatology. $2^{\text {nd }}$ ed. St Luis: Mosby Elsevier; 2008. p. 1107-14.

2. Ministry of Health Republic of Indonesia. National guidelines of leprosy control program. Jakarta: Ministry of Health Republic of Indonesia; 2012. p. 123-7.

3. Patil RR. Determinants of leprosy with special focus on children: a socio-epidemiologic perspective. American Journal of Dermatology and Venereology. 2013;2(2):5-9.

4. Barreto JG, Guimaraes Lde S, Frade MA, Rosa PS, Salgado CG. High rates of undiagnosed leprosy and subclinical infection amongst school children in the Amazon region. Mem Inst Oswaldo Cruz. 2012;107 Suppl 1:60-7.

5. Butlin CR, Saunderson P. Children with leprosy. Lepr Rev. 2004;85(2):69-73.

6. Madarasingha NP, Senaviratne JK. A study of household contacts of children with leprosy. Ceylon Med J. 2011;56(3):112-4.

7. World Health Organization. WHO expert committee on leprosy. $7^{\text {th }}$ edition. Geneva: WHO; 1998. p. 25-30.

8. Ministry of Health Republic of Indonesia. Statistics info 2014 [Internet]. [cited 2016 Sep 20]. Available from: http://www.depkes/infostatistik.

9. Fontes ANB, Lima LNGC, Mota RMS, Almeida RLF, Pontes MA, Goncales HS, et al. Genotyping of Mycobacterium leprae for better understanding of leprosy transmission in Fortaleza, Northeastern Brazil. PLoS Negl Trop Dis. 2017;11(12):1-20.

10. Yan L, Shen J, Zhou M, Zhang G. Survey on child leprosy patients and problem resulted from the disease in China. Lepr Rev. 2015;86(1):75-9.

11. Imbiriba EB, Hurtado-Guerrero JC, Garnelo L, Levino A, Cunha Mda G, Pedrosa V. Epidemiological profile of leprosy in children under 15 in Manaus (Northern Brazil) 1998-2005. Rev Saude Publica. 2008;42(6):1021-6.

12. Lee DJ, Rea TH, Modlin RL. Leprosy. In: Goldsmith LA, Katz SI, Gilchrest BA, Paller AS, Leffell DJ, Wolff K. Fitzpatrick's dermatology in general medicine. $8^{\text {th }}$ ed. New York: McGraw Hill; 2012. p. 2253-62.

13. Matsuoka M, Zhang L, Budiawan T, Saeki K, Izumi S. Genotyping of Mycobacterium leprae on the basis of the polymorphism of TTC repeats for analysis of leprosy transmission. J Clin Microbiol. 2004;42(2):741-5.

14. Weng X, Wang Z, Liu J, Kimura M, Black WC 4th, Brennan $\mathrm{PJ}$, et al. Identification and distribution of Mycobacterium leprae genotypes in a region of high leprosy prevalence in China: a 3-year molecular epidemiological study. J Clin Microbiol. 2007;45(6):1728-34.

15. Kimura M, Sakamuri RM, Groathouse NA, Rivoire BL, Gingrich D, Krueger-Koplin S, et al. Rapid variable number tandem repeat genotyping for Mycobacterium leprae clinical specimens. J Clim Microbiol. 2009;47(6):175-66. 


\section{Genotipizacija Mycobacterium leprae kod sina i oca ukazuju na mogući način prenošenja lepre: prikaz slučaja}

\section{Sažetak}

Jedan od pokazatelja uspešnosti programa Svetske zdravstvene organizacije za iskorenjivanje lepre je smanjeni broj novih slučajeva lepre kod dece sa drugim stepenom invaliditeta. Prikazan je slučaj granične lepromatozne lepre sa delimično kandžastom šakom (claw hand) kod trinaestogodišnjeg dečaka. Pregledom smo ustanovili kandžaste prste na četvrtom i petom prstu leve šake zajedno sa hipoestetskim eritematoznim plakom na oba obraza. Pacijent je takođe imao i uvećane bilateralne velike aurikularne, ulnarne i peronealne nerve. Bakteriološki pregled je pokazao da je bakterijski indeks 3+ a morfološki indeks 35\%. Rezultati histopatološkog i serološkog antifenolnog glikolipidnog-I pregleda podržali su dijagnozu granične lepromatozne vrste lepre. Genotipizacija Mycobacterium leprae različitog broja tandemskih ponavljanja kod pacijenta pokazala je 24 primerka timin-timin-citozin kao kod njegovog oca, kod kog je lepra dijagnostikovana pre 12 godina ali je bio bez adekvatne terapije. Rezultat ukazuje na mogućnost prenošenja lepre sa oca na sina. Ovaj prikaz slučaja otkriva prisustvo lepre kod dece sa multibakterijskom infekcijom koja žive sa leproznim članovima porodice. Čini se da je genotipizacija izvodljiva za epidemiološke analize prenošenja lepre.

Ključne reči: Lepra + prenošenje; Mycobacterium leprae; Granična lepra; Genotipske metode; Prikazi slučajeva

Received 8 July, 2018

Accepted 4 September, 2018 